\title{
Re-reading gender: comparative questions, situated meanings, Latin American paradoxes
}

\author{
NANNEKE REDCLIFT \\ University College London
}

\section{Introduction}

Anthropologists and critics of Western feminism have argued that AngloEuropean assumptions and concepts all too easily distort local meanings of gender (Trinh, 1989; Mohanty et al., 1991; Strathern, 1988). From a contemporary comparative perspective it has become axiomatic that different worlds demand different analytical tools, and that there is no one set of concepts or theories that is generally applicable for the understanding of sexual difference. ${ }^{1}$ Performative approaches to gender, as an activity rather than a state, also emphasize the culturally specific conceptual work that goes into marking and differentiating both masculinity and femininity (Morris, 1995), the power to fix categories and naturalize attributes that is enshrined in discourses of all kinds (Bourdieu, 1990). The analysis of gender has questioned earlier presuppositions that male and female subjects could be identified unproblematically and has examined the ways in which specific cultures actually constitute gender distinctions, through their own particular processes of signification (Yanagisako and Collier, 1987). This involves paying equal attention to the differences within, as well as between, the genders, and may also 'trouble' the stability of identities (Butler, 1990; Moore, 1993, 1994).

Thus the great strategic unities of early research, (subordination, patriarchy, status of women, escriture feminine, etc.), have given way to a paradigm of subjectivity that includes the intersection of other forms of difference, such as ethnicity, class, sexual orientation and transgender identifications (Mama, 1995; Johnson, 1997). This approach also pays particular attention to the process of representation itself, expressing the recognition that the theoretical apparatus of a critical feminism, developed in one specific historical setting, may not provide the terms for the interpretation of another. Marilyn Strathern has documented this epistemological divide with her radical critique of the applicability of the categories of Western knowledge for understanding Melanesian gender meanings. She has been at the theoretical forefront in conceptualizing Melanesian concepts of gender, (in contradistinction to the more bounded notions of the West), as having to do with the 'capabilities of relations not the attributes of things' (Strathern, 1988). ${ }^{2}$

The pitfalls of intellectual imperialism can, perhaps, hardly be avoided without such an assertion of specificity. However, it raises a further series of questions. First, in eliciting local categories for a proper understanding of how particular societies define the nature of difference, do we lack conceptual tools

\footnotetext{
${ }^{1}$ This paper was originally presented at the AHRB Workshop 'Conceptualising gender in different cultural contexts'. My thanks to the organizers Michael Worton, Nana Wilson-Tagoe and their research assistants for providing an opportunity to explore issues of context and representation, and the interface between literatures and anthropologies. The fieldwork on which it is based was carried out in between 2000 and 2002, and I thank the British Academy for their support.

${ }^{2}$ Interestingly it has still often proved difficult to conjugate the masculine and the feminine in the same breath, and the elision of gender with women, despite the flowering of interest and analysis of 'multiple masculinities' during the 1980s, is still significant (Cornwall and Lindisfarne, 1994). Purposefully so, some would say, if the original political critique is not to be lost and the attempt to broaden the terms of debate poses further challenges to theory.
} 
with which to pursue the comparative project? Cecilia Busby (1999) suggests it may sometimes be misleading to reify a West/other contrast. Examining Melanesian and Indian gender constructs, Busby finds unexpected commonalities between South Indian and Western forms of embodiment, including notions of the bounded individual as the bearer of gender. Second, comparisons tend to treat each context as a discrete gendered world. Yet research on the gendering of colonialisms, for example, has uncovered the struggle over meanings and moralities of body and sexuality, as well as the ways in which these meanings cross boundaries, interact and are articulated. Do place-specific theories, or a definitive contrast between West and other, (as well as between 'others'), risk underestimating the importance of the constant interaction and interrelationship of racial and global meanings of gender and sexuality? Transcultural processes are increasingly salient in the process of gendering. How then should we delimit the region or the place? What depth of historical contextualization should we include? Knauft (1997), comparing Melanesian and Amazonian contexts, addresses this problem by seeing regions as permeable spaces, incorporating external influences in different ways. This gives substance to the question of the gendered significance of local appropriations of modernist aspirations and fantasies, which reference an assemblage of images and icons potentially culled from diverse, not always local, sources.

In this paper I consider examples from Latin America, the classic locus of ' hybridity' and mestizaje (mixing), to examine the ways in which contemporary gender identifications draw on figurative and symbolic resources from past and present, involving both global and local modernities (Rowe and Schelling, 1991). The case of the Yucatan peninsula in south-east Mexico, with its racially diverse population of Spanish, Mayan and other groups, marked by shifting boundaries of public culture and personal history invites an examination of the nature of comparison and context. It may provide resources for thinking about other cultural settings, whether African or Asian. I use Haraway's notion of 'situated knowledge' (1991) to argue that rather than being simply 'multiple' (as in a popular current term), personal identities are patterned in certain complex but particular ways. In common with much of Central America, for instance, merely considering the forms in which the body is clothed, and the combination and transformation of possible elements, reveals key issues of self-identification, boundary drawing and cultural encounter (Hendrickson, 1995). ${ }^{3}$ Such encounters may reflect specific combinations of possibility, constraint and/or resistance. As Nencel notes, we need to consider the multiplicity of meanings surrounding male and female, without losing sight of " the relations of power which are produced and enacted in their construction' (1996: 59). A further challenge is to understand the ways in which diverse cultural references come to have situated local meanings.

\section{Is there a specific conceptualization of gender in Latin America?}

There are two possible responses to this question. First: is there any sense in which one can talk generally of 'Latin American gender'? Although such a phrase is frequently used to capture a common historical experience in relation to missionary colonialisms and state formation, the answer would have to be no, despite the shared ways in which the continent has 'been homogenized and trivialized by a Eurocentric construction' (Radcliffe and Westwood, 1993: $3)$. To ignore internal diversities would be to compound this violence. Alternatively, framing the question in another way, could one talk about a

\footnotetext{
${ }^{3}$ Friedman for a West African example (Lash and Friedman, 1992).
} 
common theoretical approach to gender in Latin America? There is possibly an affirmative answer here. Analytic approaches have tended to share an orientation, across the diverse social spaces of the continent, differentiating them, for example, from Africanist emphases or the concerns of African feminist writers (Wilson-Tagoe, 2002). This orientation is derived from the particular history of pre-Columbian and colonial inter-relationships, the theoretical legacy of Latin American Marxism, and from specific tensions with the values of Western feminism. ${ }^{4}$

The materialist analysis of the gendering of production, reproduction, politics and the state, characteristic of early research, with its focus on questions of power, households, labour, economy and social movements, had the broader significance of highlighting the exclusion of women's work, their contribution to collective action and indeed their lives, from dominant models (Redclift, 1997). It also revealed the pervasiveness of processes in which the arbitrary nature of conventional representations and stereotypes are naturalized in official and popular discourse (Bourdieu, 1990; Melhuus and Stolen, 1996; Dore, 1997). The hidden history (Dore and Molyneux, 2000) of women's productive and political experience within particular configurations of kinship and community revealed the crucial point that the process of erasure penetrated deeply into their own self-concepts. ${ }^{5}$ The habits of omission, forgetfulness and misrecognition deployed in national, official and normative discourse, constituted women as a muted group, ${ }^{6}$ anything but silent to themselves, but not represented, and frequently misrepresented, in relation to stories of nationhood, family and survival. These studies brought to light a shifting landscape, crosscut by class and ethnicity, and not easily incorporated within existing theoretical models. ${ }^{7}$ They also paved the way for more recent concerns with representation, imagery and cultural politics, pre-figured by anthropological analyses of symbolic production (Harris, 1980, 1994; Melhuus and Stolen, 1996).

The balance sheet of this twenty-year debate is first: that there is no one trajectory to be observed; second, that women had not been passive in the face of the experience of violence, or of policies that worked against their interests, but had diverse experiences that defied generalizing models of equality (Varley, 2000; Vaughan, 2000; McCallum, 2001); third, that the search for greater gender equity was not to be located in the productive or political system alone, but also in the ambiguous discourses and representations surrounding embodiment and personhood. Symbolic, metaphoric and spiritual registers provided a language through which self-representation was negotiated (Behar, 1990; Harris, 1999).

${ }^{4}$ The stereotype: 'Western women think, Latinas do ...' as a notable Latin American feminist put it. It is significant, too, that in Europe the feminist movement and academic theorization emerged simultaneously, so that the debate between theory and practice, though always highly charged, was always linked. In Latin America, by contrast, the academic debate preceded the emergence of practical politics and was closely tied to radical sociology and dependency theory as they grappled with the theoretical problems of under-development and socialism. For a fuller discussion see Redclift, 1997.

${ }^{5}$ For a lucid commentary see the contributors to Dore and Molyneux, 2000.

${ }^{6}$ A term coined by Edwin Ardener, 'Belief and the problem of women' in Ardener, 1975.

${ }^{7}$ One of the central assumptions of these early sociological studies was that the increased entry of women into the labour force would inevitably raise their status and increase their autonomy. The academic work of revealing the ideological construction of their work was meant to contribute to this process of emancipation. The flaw in this argument was that since research itself was beginning to show that the very nature of the labour market was partly constructed through gender, it was hard to see how work in itself could be a vehicle of liberation, although greater control over income has enabled some groups of women to make decisions about their own lives, to run for political office, to divorce, and so on in ways they would not have been able to do before. For a fuller comment see Redclift, 1997. Further valuable assessments can be found in Radcliffe and Westwood, 1993; Chant, 2003; Craske, 2002; and Molyneux, 2001. 


\section{Beyond materialism: paying attention to the materiality of the body}

In the Mexican context two important early works contributed to conceptions of gendered subjectivity that might bridge the analytic divide between material and symbolic approaches, though their effect is only fully bearing fruit today. Stevens (1973) drew attention to the importance of imagery in conceptualizing the gendered body and providing models for valued human qualities. She suggested that religious iconography, neglected by economistic analyses, yet such a significant vehicle for self-definition in so much of Latin America, provided an inner script for the self. It was the source of models and ideals that operated on quite a different plane to the issues of division of labour or kinship roles, yet intimately connected with all aspects of gendered experience. The stereotype of Latin machismo was, she argued, matched, by its female counterpart marianismo, the veneration of the Virgin Mary, a source of specifically female value. Spiritual symbolism constructed values, ideals and a moral landscape. It created an archetypal patterning of submission and abnegation, connected with, but also independent of, other aspects of male/female experience. A new debate about the symbolic dimensions of the self was inaugurated. At its core were ideas about the nature of the female body in relation to the natural world: open or closed, pure or impure, possessing a maternal potential, which transcended the dangerous ambiguities of the sexual. Critics of this analysis none the less noted the dangers of confusing the real and the ideal. A fuller ethnography would undoubtedly be needed to examine the working out of these ideas within the panorama of particular women's lives.

In the following decade John Ingham's ethnography of Tlayacapan, in the state of Morelos, began to give greater empirical depth to issues of self and person. In Mary, Michael and Lucifer: folk Catholicism in central Mexico (1986), he noted the contradiction that, despite the apparent anti-clericalism of the Mexican State, Catholic 'themes and patterns' are central to an understanding of concepts of the individual, the construction of masculinity and femininity and the reproduction of social relations. Religious culture provided a 'system of signification through which social order is experienced, communicated and reproduced', 'a cohesive and persistent ideological system' (1986: 1). The starting point for this analysis was a modified Durkheimianism, drawing on the principle that religious and ritual symbolism express social solidarity and distance. However, he emphasized the importance of symbolic ambiguity and transformation, stressing the need for a perspective on human action and intentionality. In Tlayacapan, religious concepts and beliefs reflect and express socio-economic and political relations. Production and the social relations of production are themselves themes of religious imagery. In examining the interrelationships of the spheres of religious belief and productive activity, he rejected aspects of Marxism, which would reduce the former to a mystification of the latter, an aspect of elite power, or a tool of political control.

Central to Ingham's analysis was the concept of reproduction, which he saw not only as an action, but as 'a root metaphor ... a concept so basic and prolific that it informed an entire world view' (1986: 185). Procreation, sexuality, agricultural and human fertility, so essential to the ecology of a community of milpa farmers, formed a domain of interlinked ideas. Renewal and regeneration were given their specific meanings through religious narrative and imagery. ${ }^{8}$ Ingham argued that the suppression of sexuality in marriage was

\footnotetext{
${ }^{8}$ The milpa system combines swidden cultivation of corn with horticultural production and is characteristically connected with rituals which emphasize regeneration and growth. According to Ingham, the origin myth of the Fall and the institution of gendered sexuality provide a semantic template for the attributes and qualities associated with notions of masculinity and femininity;
} 
coupled with male extra-marital relations, an intensification of the motherchild bond, and an oscillation between procreation and sexual abstinence. The model of the Holy Family was identified with supernatural exemplars in ritual and idiom and a 'metaphorical imbrication between the generation of plants and human beings' ( p. 59). The ethno-physiological model of conception could only be activated through the will of God, the breath of life, an evocation of the metaphor of breath as vital energy, which is also found in Andean and Mayan rural communities. The woman of the house, located within an appropriately socialized fertility, is sacred, while the woman of the street is likely to be dangerously open to the forces of evil, which are pictured as both acquisitive and hyper-sexual.

The importance of both these pieces of work is that, rather than taking the body as a given, they attend to the precise way corporeality is given meaning. They indicate that the body is always actively present and actively imagined. ${ }^{9}$ The materiality of the body is not static but dynamic and processual, envisaged through a language that connects it to other beliefs. However, they also raise a number of problems. Individual case studies, so good at unpacking the specificities of a local world view, sometimes tend to be taken up as diagnostic of the general state of affairs and particular social worlds risk becoming overgeneralized to society at large. The value of such studies is the particularity to be derived from definable units, classes, movements, congregations, or communities. Stevens' idealized template and Ingham's exclusionary reproductive model privilege a normative heterosexuality which pre-dates more recent attention to alternative sexualities. To what degree do such unifying models reflect the contradictory and contested nature of experience, the negotiation or rejection of such idealizations? Whilst materialist emphases tended to ignore ethnicity in favour of class, later work sometimes seems to imply that an ethnic, gendered cosmovision is evenly distributed inside the little community, and perhaps even beyond it. The model itself is presented as more or less applicable to the group, offering a general social script specific to the culture, understood as a highly local phenomenon.

Further, a conceptual emphasis on iconic representations does not necessarily tell us about their reception or consumption. Who reads/imagines in what way? Where do such archetypes or images do their 'work' and where are they transgressed? How are they developed or changed? These models, for women and for men, tend to be seen as complete and encompassing, with little access to dissent or challenge, or room to wonder how, for example, the lives of Tlacapenos, as they increasingly become migrants, wage workers, or Protestant converts, might be lived within such a matrix.

The 1990 s witnessed a major rethinking of the sex/gender concept. ${ }^{10}$ As Judith Butler (1993) notes, bodies 'matter'. The point is how, for whom and under what terms of choice or constraint. In anthropology the diverse ways in which peoples in different contexts 'make meaning out of matter' (Broch-Due,

\footnotetext{
the conception, passion and resurrection of Christ are mapped onto local understandings of the relations between the social and the spiritual world and the human experience of birth, death and continuity.

${ }^{9}$ They preceded and paralleled, though do not directly reference, the emerging theoretical questioning of the clear separation of the concepts of sex and gender, seen as an unchanging biology versus a variable socially constructed set of gender arrangements. In the context of Western feminist debate philosophers such as Moira Gatens argued that rather than a prediscursive physical fact, there is no body outside the language, models and images we use to give it meaning. For example women's bodies are the site of birth, but the significance and implications of this potentiality can be understood and lived out in many different ways.

${ }_{10}$ This has challenged the view that cross-cultural variations in gender categories are merely diverse elaborations of the same natural fact.
} 
1993: 53) has given rise to a rich set of new ethnographic explorations. The advent of studies of masculinity, and the investigation of the social context of aids and homosexuality, have played a crucial role in pushing this debate towards more complex accounts of identity (Murray, 1995; Prieur, 1996; Carrier, 1997; Balderston and Guy, 1997; Balderston, 1997; Buffington, 1997). In Mexico, for example, the language of machismo has often been presented as the quintessential essence of maleness, classically exemplified by Oscar Lewis's portrayal of Jesus Sanchez. ${ }^{11}$ Memorably portrayed in fiction by Juan Rulfo's Pedro Paramo (1955), it could also be interpreted as the space of loss that lies outside male games of rivalry and revenge (Franco, 1989: 131). This machismo is constituted by a contradiction, consisting of courage, generosity and stoicism as well as arrogance and vainglory, in which the swagger of outward appearances and empty boasts conceals an inner vulnerability.

Rather than enshrining such self-beliefs as essential attributes, newer interpretations have deconstructed them as discourse, aspired to or rejected, reflecting a 'positional consciousness', which is expressive and performative, activated by some men, contested by others, contextually recognized rather than totalizing, and deeply marked by ethnic difference (Gutmann, 1996). Incorporating elements of defence against the potential racist feminization of the indigenous male, as well as the 'Northern' denigration of supposed Hispanic stereotypes, the essential ambiguity of such postures is exposed (Harris, 1994). Connections have also been drawn between the advent of machismo, as a construct of modernity, and the expansion of nationalism, racism and international relations, revealing the broader politics to which such concepts relate. As Lancaster (1992) notes, in national allegories the androcentrism of modern political imaginings often portrays 'woman' as the territory over which the search for male national identity is pursued. His own work, as well as that by others mentioned above, reveals the mutual constitution of homosexual, heterosexual and bi-sexual constructions and the limitations of these very terms themselves for a culturally nuanced understanding of male sexual subjectivities.

Normative valuations of the female and significations of the feminine must be equally amenable to such multifaceted analysis. Literary and creative expression can be a crucial guide to the subtleties and indeterminacies of personal experience, able more easily to express the tensions, fantasies and ambiguities that transcend totalizing models. In the Latin American context, the central importance of the diverse meaning of local metaphors and images provides an important prelude to this work. In the next section, therefore, I re-examine some of the previous ideas from the perspective of plurality and 'reading', posing some questions to the icons and stereotypes discussed. Familiar emblematic figures, which offer imagined and encoded representations of gender, are considered from the viewpoint of some of the popular daily allusions, readings and re-readings to be observed in contemporary Yucatan.

\section{Syncretic images, hybrid cultures? Gendered texts and cultural politics}

The concept of readership is a useful term through which to develop this debate. The duality of emblematic figures, such as the Mary/Eve contrast, is self-evident. The ways in which they are woven into the moral landscape of everyday life, espoused by some, flouted by others, has received less attention.

\footnotetext{
${ }^{11}$ His often quoted apologia for heroic manhood: 'In a fight I would never give up or say, "Enough", even though the other was killing me. I would try to go to my death smiling. That is what we mean by being "macho", by being manly" (Lewis, 1961: 38).
} 
Yet in Latin America we are dealing not only with an enormous cultural diversity, but also a highly metropolitan society, with a huge urban middle class, a major history of migration, and transnational networks as fine as spiders' webs reaching into the most isolated community. In the multi-regional 'Maya world', extending from El Salvador to Chiapas, there are thirty-three different and mutually unintelligible languages spoken in addition to the dominant Spanish, and diverse patterns of migration, incorporation and differentiation. We must also account for the ever-present and continuing legacy of an ancient colonialism, which has suppressed, syncretized or imperfectly integrated aspects of other world views, spiritualities and kinds of knowledge. ${ }^{12}$ Contemporary ethno-historical research demonstrates that this was a process of re-signification and transformation that was never fully completed. As Irene Silverblatt (1987) has shown for the Andes and Peter Sigal (2000) for the Yucatec Maya, pre-Columbian signs of gender were re-inscribed with new meanings in the process of conquest (see also Trexler, 1995). Contemporary cultural politics and pan-Maya movements for cultural revitalization reflect attempts to re-incorporate some of these meanings in the present.

The symbol of the Virgin, for example, is not simply an abstract idealization but a presence inextricably associated with the encounter between worlds, and the colonialism of hearts and minds. In the contemporary ethnically plural world of Yucatan there is a deeper ideological conjuncture between understandings of the natural world, the capacity of the supernatural to express itself in the form of apparitions, and numerous and continuing instantiations of the Virgin in the form of miraculous appearances. She is associated with maize, water and honey, the symbolic power of the Moon (associated in Maya cosmology with the goddess Ixchel) and the serpent (representing wisdom and knowledge), in continuing contradistinction to Christian representations. The sacred spaces of caves, cenotes (water sink holes) and ruins, are elided with local notions of the Virgin to produce an imaginative fusion which is not necessarily coterminous with European readings (Vargez Pasos, 2000; Quintal Aviles, 2000; cf. Harris, 1988).

The most powerful exemplar, however, is that of the Virgon de Guadaloupe, the indigenous virgin who appeared to the Indian Juan Diego, in the Sierra de Tepeyac above Mexico City in December 1531, ten years after the Spanish conquest. She has become one of the most revered Marian icons in the continent, if not the world. Her shrine and veneration have often been interpreted as specific to women, reflecting the standard evaluation of the symbol of the Virgin that we have already seen suffering, patient and abnegated, exemplifying Stevens' conceptualization of marianismo as a model of submissive female behaviour. In the context of the ideas I have been developing this interpretation seems too limited and one-dimensional.

The practices of worship that can be observed today, which include men and women, young and old, exceed the idealization of virtue in which Mary is 'alone of all her sex' (Warner, 1985), to condense more multiplex and panoptic ideas. Why, for example, do men now make up such a multitude of her pilgrims, running huge distances as Antorchistas (torchbearers) in trials of endurance? Why do men, in particular, make promesas (promises) and construe acts of physical fortitude as penitence? Why do there continue to be 'miraculous' apparitions of different forms of the Virgin in this part of south-east

${ }^{12} \mathrm{cf}$. 'One forgets that all Christian churches are by definition syncretistic. The problem is only that we do not recognize our own syncretism as such.' Walter Hollenweger http://www.apts.edu/sjps/99-1/99-1-w-hollenweger.htm 
Mexico? The history of the cult and the creation of a mytho-poetic rendition of the supposed miracle suggest alternative viewpoints.

Recent scholarship indicates that the vision of Guadaloupe took place at an existing indigenous sacred site, honouring the goddess Tonantzin, who in common with other pre-Columbian deities combined both powers of fertility and of destruction, both maternity and powerful sexuality, both male and female aspects (Brading, 2001). As expressed by the chronicler Fray Bernardino de Sahagun, the Spanish regarded the persistence of this cult as both idolatrous and subversive. The appearance of the miraculous dark-skinned Virgin to the already Christianized Indian is a striking expression of both unification and resistance, in which a point of convergence could be metaphysically articulated providing a cohesive symbol for the heterogeneous society that was emerging. The shrine of Tonantzin was reborn in a new and revitalized form, one which appeared to subsume the many tensions and attempts at suppression that had surrounded it in the previous decade. 'Non fecit taliter omni natione', a like thing has not been done in any other nation, wrote the scribe of the original account, providing a triumphant legitimation and justification for the New Spain that was being forged from conquest.

Unlike other incarnations Guadaloupe is always represented alone, without the infant Jesus, emphasizing singularity, and also the directness of her relationship with the viewer, with the people, and with the nation. Her head is invariably inclined slightly to the right, with eyes that are less downcast than receptive, as if listening. The narrative tells of her words to Juan Diego as 'the smallest of all my children'. It thus captures the sense of racial abnegation, but also the Indian's own inclusion and ennobling as divine messenger. One of the proofs she gives him to convince the bishop of the veracity of his vision is the imprint of her image on his tilma, or tabard, the very marking of herself on his body, epitomizing the power of the maternal figure in relation to vulnerable offspring.

New scholarly analysis of the indigenous substrate of the image is also paralleled by a popular return to this original source, as theological debates filter gradually into local expressive repertoires. As a neighbourhood priest explained to me, 'You must realize that the importance of the miraculous image for our congregation here is an existential one. We now know that the figurations on her dress and mantle can be deciphered to reveal a specifically Nahuatl meaning. Such things speak to our indigenous people'. This recent interpretation suggests a meaning that both encompasses and supersedes the idea of the Virgin as either an authentic reflection of a timeless natural world, or as a colonizing Catholic signifier. Such readings appear to re-appropriate the Western or global image, which has already been partly syncretized with pre-Columbian meanings during the course of the previous 450 years, and tacitly position it to re-embody its indigenous characteristics.

This particular image of the Virgin is thus difficult to associate only with suffering womanhood. There is little hint of abnegation in this presence but rather a transcendent manifestation of power, authority and encompassment. In addition to the popular genre of Catholic hagiography in pamphlets, devotional poems and songs, the last fifteen years have also seen the expansion of a newer literary reflection on the lived meaning of this presence. As the Chicana writer Ana Castillo writes of her childhood 'I saw that beautiful Indian woman as the Mother-God. God the father was absent, in the same way as the men in my family, who were often obscure and silent. While He saw us with a meticulous and critical eye, dispensing his power with fear. She protected us without condemnation' (Castillo, 1991: 74). The marketing of the image on 
commercial products of all kinds has also hugely expanded, providing further moments for comment and reflection. A supermarket cashier, selling new Virgin of Guadaloupe phone cards, remarked almost casually, 'there, that's the strength of all women'.

More than just a model of female duty, she is also unequivocally Mexican, capable of providing an integrative vision for a uniquely plural and fractured society. As people invariable say today, she is 'ours', choosing to reveal herself in Mexico, rather than elsewhere. Some therefore constitute her less as the mother of Christ than as a female image of God, expressing a unifying maternity, which subsumes both male and female in its generative yet intimate power. The men who run as torch-bearers for the Virgin today, speak of the power to change, the promise of being 'better husbands and fathers', of renouncing alcohol, of loving their children more, a commitment to transformation to which they aspire. It is easy to see why nationalism is deeply woven into the significance and promotion of this vision, and into the more recent expansion of her cult today. Her potency seems to provide a space of mediation for both sexes, which is unavailable elsewhere.

The Catholic orthodoxy may attempt to deny the heterodox possibilities of the 'new' miraculous apparitions, in trees, ruins or window-panes, that continue to flourish in Yucatan. It may also try to 'domesticate' them by orchestrating the local manifestations within the more 'nationalizing' cult of the 'originary' Guadaloupian narrative. Within these 'incorporated' devotions, in which the Church tries to expand its constituency while securing its authority, there is also a struggle to maintain order over the potential excesses of pilgrims and antorchistas, about whom local priests express a certain ambivalence. But popular manifestations also to some extent escape official control (Varguez Pasos, 2000), expressing the tensions and fusions between indigenous and Hispanic forms of signification, a dialogue in which Virgins and 'idols' continue to be conjugated (Quintal Aviles, 2000), a crucial vehicle for specifically local kinds of identification.

Equally, we cannot ignore the expansion of Evangelical movements across the continent, deeply averse to such mythic visions. These offer a different kind of new model for women and 'for men, as well a way of contesting existing expressions of political authority. In the context of Yucatan, women are often the most active initiators and participants in these new congregations, as they have been in indigenous movements (Rosenbaum, 1993; Goodman, 2001; Nash, 2001) and deliberately distance themselves from neighbourhood and communal Marian devotions. As in the case of the Virgin, Protestant idioms can also be seen as Western, but they, too, are syncretic, expressing productionist, familistic values, incorporated and integrated into Mayan or mestizo conceptions of body and self.

While in no sense reconstituting Mary as an unequivocal figure of promise for women, it appears that both liberation theology, popular faith and movements for ethnic revitalization are able to derive new meanings from the icon that are themselves socially dynamic. The question, therefore, is not so much what we find in the Virgin, imposing a one-dimensional interpretation of a universal meaning, but what is or may be found in her, as an 'encoded figure', whose situated meaning is sensitive to diverse contexts and epochs. A functionalist interpretation conceals a million other questions. Exactly who worships her and in what way? Where does the image 'live' in relation to personal experience? Both chaste (universalistic) and empowering (local) readings may be present, mobilized by different kinds of worshippers or rejected entirely. In 
the vicinity of such an image how do these readings construct identities and practices in dialogue with other emblematic forms?

\section{Icons and anti-icons: demons, divas and Queen Victoria}

In common with other Mesoamerican narrative traditions, the image of the Virgin does not subsume all available representations. It has its antithetical counterpart in other stories. In addition to the familiar Virgin/Eve dialogue, there are other female beings with apparently negative, but also possibly ambiguous, power. Sometimes these are seen as having a real history, as in the form of La Malinche, the Indian woman who became the consort of Cortes, and the betrayer of her people. The physicality of La Malinche, either as malevolent traitor or passive victim, is graphically expressed in everyday speech as La Chingada, literally 'she who was fucked' or by implication she who fucked us. ${ }^{13}$ This demonic counter-narrative occurs in south-eastern Mexico in the form of a more mythic, supernatural creature, with long hair and clawed feet, metamorphosing in the shade of the ceiba tree, the sacred tree of Maya cosmology. Her malevolent beauty has the power to entrap men who are unlucky enough to meet her in the forest. In Yucatan, she is known in the Maya oral tradition as the Xtabay, one among a number of supernatural entities. These include the yuntzilo'ob or lords protecting spirits of the forest, water and milpa, whose presence is manifested through noises, whistles and footsteps, the aluxes, troublesome fairies, and the uayes, malevolent spirits who take animal form.

The Xtabay, too, is currently undergoing something of a transformation. Many people can tell of encounters with her by family or neighbours, and these personal narratives combine with other oral accounts and increasingly pass into written form. In this genre, descriptions are often reduced to a minimum, presupposing considerable cultural competence on the part of the receiver. Thus elements necessary for understanding pass from voice to voice and 'surpass the text' (Rosado and Rosado, 2001), leaving empty spaces capable of being filled by the cultural expectations and repertoires of other receivers or readers. This renders them susceptible to further interpretations. Such plasticity allows the incorporation of new elements, by members inside or outside the cultural group, and the loss of others. Thus there have been ' external', Christianizing ethical interpretations, direct transcriptions of oral tradition by anthropologists and others, and renditions from indigenista (proindigenous) political sympathizers who may often be 'white' intellectuals.

Until recently demonizing representations have predominated, but indigenous scholars have now begun their own labour of rediscovery. A new genre of Mayan writing, particularly by women, has begun to re-examine and re-express the sources of the oral tradition (Rosado and Ortega, 2001). Transcripts and versions of the stories by members of the Maya revitalization movement, the movements for linguistic autonomy, and new Mayan writers themselves, are permeating written and visual genres, in workshops, broadsheets, journals and murals. Particularly in the southern part of the region, where the history of resistance to Spanish domination is still alive, re-interpretations note that negative readings of the Xtabay may represent a Christian-influenced transformation of the Maya goddess Ixtab. The gods of the Maya pantheon were not only variously sexual, but as a positive aspect of their regenerative powers they were uniters of duality, seen not as contradiction but as complexity, containing both destructive and beneficial, male and female elements. The

\footnotetext{
${ }^{13}$ See, for example, Alarcon, 1981.
} 
specific role of Ixtab was to lead suicides to paradise, to which they were thought to have favoured entry. Far from being the temptress of weak men or embodying a dangerous sexuality, she was seen as the conduit of an inspired vision of the integration of death and life. Her accompanying serpent was not the harbinger of sin, as in the Christian interpretation, but a symbol of knowledge, a path to enlightenment (Leon Diez, 2002). For example, in order to practise the craft of embroidery (Xoc bil chuy or counted stitch), a practice so central still in much of the region, women should pass their hand five times over a snake. The power of the serpent conveyed special knowledge, a habitus of geometry, a dual configuration of creativity both mental and physical. The fear and disgust this inspired in the conquerors generated the overlay of a representation consistent with a Christian moral environment. Two other mythic figures also suggest this contrast with Christian concepts of sexuality. They are Utskoolel, who is chaste but who is also cold, associated with the dry flower of taakan or cactus, and Xkaban, the fully sexual being, noble and giving, whose flower is the aromatic Xtabantun, sweet, simple and fragrant. A recent, almost life-size, painting of the Xtabay by the Mayan artist Marcelo Jimenez emphasizes the force and mystery of her form, while significantly omitting the cloven feet which make her monstrous. Thus, while the symbol of the Virgin has often been presented as if it conveyed all there was to say about the template for female behaviour, it is obviously a symbol which co-exists with many others, which may be resignified and repositioned in various ways.

Social science has not always found it easy to engage with dimensions of irony and parody but has begun to develop new ways of thinking about ambiguity and incoherence, stimulated often by literary theory. Even as the local, predominantly rural, world of south-east Mexico examines the past to recreate itself, it has long existed within the evolving landscape of national and international discourses, styles and fantasies and is increasingly penetrated by the visual needs of tourists and foreigners. The power of the ability to subvert religious and racial meanings could hardly be expressed more clearly than by that epitome of Mexican surrealism for an international post-feminist audience, Frida Khalo. As a commodity Kahlo's painting spreads out beyond its elite location, and has become available to provincial, as well as transnational audiences, as an international export of mexicanidad. Her doubled self-portraits disrupt the false clarity of the indigenous/mestizo/white continuum. They defamiliarize and distort the meaning of the maternal body, the European nude, the Catholic icon, the viewer's gaze (Franco, 1989; Chedzgoy, 1995). ${ }^{14}$ Tourist networks have become the primary conduits for the diffusion, (and often ambivalent) reception, of such metropolitan representations. Playing with the hysterization that lies behind the normative and normalized body, the mutilated narcissism of the Frida postcard confronts expected obligations. Even if the postcard seller in the square will only hazard a view that they are

\footnotetext{
${ }^{14}$ Compare, for example, Davila's painting of a transsexual Simon Bolivar. As Masiello (1997: 220) notes, 'Davila's work ... interrogates fixed notions of identity passed on from founding fathers ... (it) reminds us that the national project depends on a masculine heterosexual body to organize memory and history. It also suggests that others have the right to construct an image of the national hero and to reverse the common aesthetic and symbolic legacies that have excluded considerations of gender. In the same vein, Davila shows us that patriotism is also a commercial construct, based on the wholesale packaging and trade of poses, gestures styles and dress ... from the time of the nineteenth-century independence wars through the recent transition to democracy, patterns of dress and sexuality have formed part and parcel of the Latin American political imagination. Toward the century's close, the marketing of gender images and dress served the liberal state as a vehicle to modernize culture'.
} 
'fea' (ugly), or ' raro' (strange) they are passing in an uneven, intangible and inconsistent way into a wider visual field.

While some national icons become globalized, as Frida has been, others create themselves from transcultural elements and styles. The televisual explosion of dialogues and alternatives creates a further space of situated meanings. The Mexican actress Maria Felix, who died in 2002, was the perfect fusion of Hollywood star and European diva, and the mourning surrounding her funeral matched that of a head of state. The press extolled her charisma, magnetism and character, using the latter almost as a euphemism for that enactment of the absolute self, the confusion of character with the power to be selfish, which was her most notable quality. In an extraordinary valedictory oration, the president, Vicente Fox, praised her 'contribution to democracy', while the ex-director of the Institute of Fine Arts claimed that she was, "the prototype of the Mexican woman of the twenty-first century'. For someone who had not the slightest concern with politics, who had benefited all her life from corruption, who despised Mexico City because it was not Paris, these were bizarre sentiments (Gomez Rivera, 2002). About a person who had not the slightest acting talent, who had used her amorous relationships to further her career, who died rich but apparently incapable of feeling, they could only reflect the excess which wealth, celebrity and cinema can manufacture.

Although one might assume that as icon 'La Doña' reflected the fantasies of the mestizo urban working or middle classes, in the so-called 'Zona Maya' as among many other groups, her death was also met with an outpouring of grief. Many women extolled her as enviable and to be emulated. 'She was my ideal', said a notable local Maya activist, one of the key members of the newly formed Academy of Mayan Culture and Linguistics, 'she represented women's capacity to choose what to be'. 'She did what she wanted to do and expressed herself', according to a shopkeeper, 'she made the most of men' said another. Equally a model for women, therefore, is the diva-demon, someone who chose to break almost entirely with the maternal image, who placed acquisitiveness above nurturance, who used men rather than being used. Perhaps one image is not complete without the other.

Finally, an even stranger encounter of distant worlds indicates that these syncretic forms are long-standing and pervasive. The southern part the state of Quintana Roo, the 'zona Maya' is also the territory of the cruzo'ob, descendants of those who mounted one of the most important episodes of resistance to Spanish domination in the nineteenth century. Some still live in the military-theocratic communities that were the base of their resistance. Members of the expanding indigenous cultural movement are active in retelling their history through various media, local radio, painting, muralism and artisan press.

One of these stories, both told to me and recently reprinted in a new local cultural monthly, recounts the adventures of a famous Federal teacher, Pacheco Cruz, who was sent to re-organize education in the new territory in the early years of the last century, and who was struck by the assertiveness of cruzo'ob women. On trying to discover the source of their authoritative behaviour, indigenous women themselves informed him that this dated to the era in which the rebel Maya had an intense commercial exchange with the population of Belize. Maya women used to accompany their husbands to the English colony, to buy provisions and arms to pursue their struggle. There they became aware of the respect and obedience towards Queen Victoria that her subjects professed. They even opened negotiations to try to be taken under the English crown, and hung the Union Jack in their home villages. The relationship of 
'subordination towards a feminine figure' that they perceived among the British, struck them as admirable, and much to be emulated, so the account goes. It was transferred, and became embedded in the symbolic universe and everyday interaction of the Maya population of the region (Nichte Tan, 2001). Apocryphal as this story may be, it offers further indication that the interactive transcultural nature of meaning-making is no new phenomenon. Nor can the concept of hybridity be casually deployed. It must eschew any easy dichotomy between notions of harmonious fusion or forced appropriation, the polarization between 'noisy authority or silent repression of tradition' (Bhabha, 1994: 102). Rather than an achieved state it is precisely the undecidability of these forms and processes, the gaps in the 'text' that can be filled by participants, that allows them to be subject to continual re-reading and potential subversion.

\section{Conclusion}

This paper has examined some of the questions surrounding the notion of cultural context in the study of gender. The materialist perspective in Latin American research has been complemented by an understanding of the materiality of the body, read and imagined through numerous, often competing, scripts. Among these the spiritual dimension, whether in relation to Christian iconography or indigenous cosmovision, has received particular attention. Yet, like other texts these are 'mobile' (Still and Worton, 1993), mutable and co-produced by readers, who bring to them other histories of embodiment and meaning, as well as conjugating them together with other apparently discrepant narratives.

Contrasts reveal particularity and challenge assumptions. However, gendered identifications also transcend simple notions of place. The terms of the comparative project are therefore changing. An exploration of social memory and the imagination reveals the syncretism of spiritual symbolization, the hybridity of diverse histories and values. These forms in themselves are not finished but in the process of dialogic interpretation. The mythic figures and 'ideal' models that have been discussed do not exemplify the real, or reflect behaviour. Yet in examining some of the diverse ways they come to be read in the particular context of south-east Mexico, the active construction of meaning can be explored. These 'envisionings' and re-visionings expand temporal and spatial location to incorporate wider values and aspirations, articulated in situated understandings, to reflect a variety of discursive standpoints. Creative modes, whether visual or written, both emerge from and stand apart from their cultural context. Iconography, literature and the imagination provide entry points to the ambiguities of the inner self. They offer a window through which to consider the extent to which the imagined gender cosmologies of contemporary societies are multi-layered and multi-vocal.

\section{REFERENCES}

Alarcon, N. 1981. 'Chicana feminist literature: a re-vision through Malintzin, or Malintzin, putting the flesh back on the object' in C. Moraga and G. Anzaldua (ed.), This bridge called my back: writings by radical women of color. Watertown, MA: Persephone, 182-90.

Ardener, S. (ed.). 1975. Perceiving women. London: J. M. Dent.

Balderston, D. and Donna Guy. 1997. Sex and sexuality in Latin America. New York and London: New York University Press.

Balderston, D. 1997. 'Excluded middle: bisexuality in Dona Herlinda y su hijo' in D. Balderston and D. Guy (ed.), Sex and sexuality in Latin America. New York and London: New York University Press, 190-99.

$\rightarrow$ Behar, R. 1990. 'Rage and redemption: reading the life story of a Mexican marketing woman', Feminist Studies, 16/2: 223-58.

Bhabha, H. 1994. The location of culture. London: Routledge. 
Broch-Due, V. 1993. 'Making meaning out of matter: perceptions of sex, gender and bodies among the Turkana' in V. Broch-Due, I. Rudie and T. Bleie (ed.), Carved flesh, cast selves: gendered symbols and social practices. Providence and Oxford: Berg.

Bourdieu, P. 1990. The logic of practice. Cambridge: Polity Press.

Brading, D. 2001. Mexican Phoenix: Our Lady of Guadalupe, image and tradition across five centuries. Cambridge: Cambridge University Press.

Buffington, R. 1997. 'Los Jotos: contested visions of homosexuality in modern Mexico' in D. Balderston and D. Guy (ed.), Sex and sexuality in Latin America. New York and London: New York University Press.

Busby, C. 1999. 'Permeable and partable persons: a comparative study of gender and body in India and Melanesia', Journal of the Royal Anthropological Institute (NS), 3: 261-75.

Butler, J. 1990. Gender trouble: feminism and subversion of identity. New York and London: Routledge.

Butler, J. 1993 Bodies that matter: on the discursive limits of sex. New York and London: Routledge.

Carrier, J. 1997. De los otros: intimacy and homosexuality among Mexican men. New York: Columbia University Press.

Castillo, A. 1996. Goddess of the Americas. La diosa de las Americas. Writings on the Virgin of Guadalupe. New York: Riverhead Books.

Chant, S. 2003. Gender in Latin America. London: Latin America Bureau.

Chedgzoy, K. 1995. 'Frida Kahlo's grotesque bodies' in P. Florence and D. Reynolds (ed.), Feminist subjects, multi-media. Manchester: Manchester University Press.

Craske, N. 2002. Gender and the politics of rights and democracy in Latin America. Basingstoke: Palgrave.

Cornwall, A. and N. Lindisfarne. 1994. Dislocating masculinities. London: Routledge.

Dore, E. 1997. Gender politics in Latin America: debates in theory and practice. New York: Monthly Review Press.

Dore, E. and Molyneux, M. (ed.) 2000. Hidden histories of gender and the state in Latin America. Durham, NC: Duke University Press.

Franco, J. 1989. Plotting women: gender and representation in Mexico. New York: Columbia University Press.

Franco, J. 1997. 'From the margins to the centre: recent trends in feminist theory in the United States and Latin America', in E. Dore (ed.), Gender politics in Latin America: debates in theory and practice. New York: Monthly Review Press.

Goodman, F. 2001. Maya apocalypse: seventeen years with the women of a Yucatecan village. Bloomington and Indianapolis: Indiana University Press.

Gomez Rivera, Maria. 2002. 'Solamente Maria, Pobre Dona' in Diario de Yucatan, 12 April: 4

Gutmann, M. 1996. The meanings of macho: being a man in Mexico City. Berkeley and Los Angeles: University of California Press.

Haraway, D. 1991. Simians, cyborgs and women: the reinvention of nature. London: Free Association.

Harris, O. 1980. 'The power of signs: gender culture and the wild in the Bolivian Andes' in C. MacCormack and M. Strathern (ed.), Nature, culture and gender. Cambridge: Cambridge University Press.

Harris, O. 1988. 'La Pachamama: significados de la madre en el discurso Boliviano', Mujeres Latinoamericanas: diez ensayos y una historia colectiva. Lima, Peru: Flora Tristan, Centro de la Mujer Peruana.

Harris, O. 1994. 'Condor and bull: the ambiguities of masculinity in Northern Potosi' in P. Gow and P. Harvey (ed.), Sex and violence: issues in representation and experience. London: Routledge.

Harris, O. 1999. To make the earth bear fruit. London: Institute of Latin American Studies.

Hendrickson, C. 1995. Weaving identities: constructions of dress and self in a highland Guatemala town. Austin, TX: University of Texas Press.

Ingham, J. 1986. Mary, Michael and Lucifer: folk Catholicism in central Mexico. Austin, TX: University of Texas Press.

Johnson, M. 1997. Beauty and power: transgendering and cultural transformation in the Southern Philippines. Oxford: Berg.

$\rightarrow$ Knauft, B. 1997. 'Gender, identity, political economy and modernity in Melanesia and Amazonia', Journal of the Royal Anthropological Institute, 3/2: 233-59.

Lancaster, R. 1992. Life is hard: machismo and the intimacy of power in Nicaragua. Berkeley and Los Angeles: University of California Press.

Lash, S. and J. Friedman (ed.). 1992. Modernity and identity. Oxford: Blackwell.

Leon Diez, M. A. 2002. 'El bordado en la zona Maya', Nichte T'an 2:13.

Lewis, O. 1961. The children of Sánchez: the autobiography of a Mexican family. New York: Random House.

Mama, A. 1995. Beyond the masks: race, gender and subjectivity. London and New York: Routledge.

Masiello, F. 1997. 'Gender, dress and market: the commerce of citizenship in Latin America' in D. Balderston and D. Guy (ed.), Sex and sexuality in Latin America. New York and London: New York University Press.

McCallum, C. 2001. Gender and sociality in Amazonia: how real people are made. Oxford: Berg.

Melhuus, M. and K.-A. Stolen. 1996. Machos, mistresses and Madonnas: contesting the power of Latin American gender imagery. London: Verso. 
Mohanty, C., A. Russo and L. Torres (ed.). 1991. Third world women and the politics of feminism. Bloomington and Indianapolis: Indiana University Press.

Molyneux, M. 2001. Women's movements in international perspective: Latin America and beyond. Basingstoke: Palgrave.

Moore, H. 1993. 'The difference within and the difference between' in T. Del Valle (ed.), Gendered anthropology. London: Routledge, 193-204.

Moore, H. 1994. A passion for difference. Cambridge: Polity Press.

$\rightarrow$ Morris, R. 1995. 'All made up: performance theory and the new anthropology of sex and gender', Annual Review of Anthropology 24: 567-92.

Murray, S. O. (ed.). 1995. Latin American male homosexualities. Albuquerque: University of New Mexico Press.

Nash, J. 2001. Mayan visions: the quest for autonomy in an age of globalization. New York and London: Routledge.

Nencel, L. 1996. 'Pacharacas, putas and chicas de su casa: labelling, femininity and men's sexual selves in Lima, Peru', in M. Melhuus and K.-A. Stolen (ed.), Machos, mistresses and Madonnas: contesting the power of Latin American gender imagery. London: Verso.

Nichte T'an Revista de Arte, Cultura e Historia Regional Vol. 1, 2001.

Prieur, A. 1996. 'Domination and desire: male homosexuality and the construction of masculinity in Mexico', in M. Melhuus and K-A. Stolen (ed.), Machos, mistresses and Madonnas: contesting the power of Latin American gender imagery. London: Verso.

Quintal Aviles, E. 2000. 'Virgenes e idolos: la religion en las manos del peublo', Mesoamerica 39, June: $287-304$.

Radcliffe, S. and S. Westwood. 1993. Viva: women and popular protest in Latin America. London and New York: Routledge.

Redclift, N. 1997. 'Post-binary bliss?' in E. Dore (ed.), Gender politics in Latin America: debates in theory and practice.

Rosado Aviles, C. and O. Ortega Arango. 2001. 'Los labios del silencio: la literatura femina Maya actual' in G. Rosado Rosado, Las mujeres Mayas: siglos tejando una identidad. Mexico: Conaculta, Fonca.

Rosado Rosado, G. and C. Rosado Aviles. 2001. 'De la voz a la escritura: la figura feminina en los mitos Mayas' in G. Rosado Rosado, Las mujeres Mayas: siglos tejando una identidad. Mexico: Conaculta, Fonca.

Rosenbaum, B. 1993. With their heads bowed: the dynamics of gender in a Maya community. Albany, NY: State University of New York Press.

Rowe, W. and V. Schelling. 1991. Memory and modernity: popular culture in Latin America. London: Verso.

Rulfo, Juan. 1964 (1955). Pedro Paramo. Mexico: Fondo de Cultura Economica.

Scheper-Hughes, N. 1992. Death without weeping. Berkeley and Los Angeles: University of California Press.

Sigal, P. A. 2000. From moon goddesses to virgins in the colonisation of Yucatecan Maya sexual desire. Austin, TX: University of Texas Press.

Silverblatt, I. 1987. Moon, sun and witches: gender ideologies and class in Inca and colonial Peru. Princeton: Princeton University Press.

Strathern, M. 1988. The gender of the gift. Cambridge: Cambridge University Press.

Stevens, E. 1973. 'Marianismo the other face of machismo in Latin America' in A. Pescatello (ed.), Female and male in Latin America. Pittsburgh: Pittsburgh University Press.

Still, J. and M. Worton (ed.). 1993. Textuality and sexuality: reading theories and practices. Manchester: Manchester University Press.

Trexler, R. 1995. Sex and conquest: gendered violence, political order and the European conquest of the Americas. Ithaca, NY: Cornell University Press.

Trinh, T. M. 1989. Woman, native, other: writing postcoloniality and feminism. Bloomington and Indianapolis: Indiana University Press.

Varley, A. 2000. 'Women and the home in Mexican family law' in E. Dore and M. Molyneux (ed.), Hidden histories of gender and the state in Latin America. Durham, NC: Duke University Press, 238-61.

Vargez Pasos, L. 2000. 'De virgenes y apariciones: representaciones religiosas entre los mayas y clases populares de Yucatan', in G. Negroe Sierra and F. Fernandez Reppeto (ed.), Religion popular de la reconstruccion historica al analysis antropologico. Merida, Yucatan: Ediciones de la Universidad Autonoma de Yucatan.

Vaughan, M. K. 2000. "Modernizing patriarchy: state policies, rural households and women in Mexico 1930-1940' in E. Dore and M. Molyneux (ed.), Hidden histories of gender and the state in Latin America. Durham, NC: Duke University Press, 194-214.

Warner, M. 1985. Alone of all her sex: the myth and cult of the Virgin Mary. London: Picador.

Wilson-Tagoe, N. 2002. 'Shaping African feminist thought', paper given in the AHRB African and Asian Literature Seminar Series, 11 March..

Yanagisako, S. and J. Collier. 1987. Gender and kinship: essays towards a unified analysis. Stanford: Stanford University Press. 